\title{
$\beta$-Adrenoceptor Function in White Blood Cells from Newborn Infants: No Relation to Plasma Catecholamine Levels
}

\author{
LARS O. BOREUS, PAUL HJEMDAHL, HUGO LAGERCRANTZ, ARNE MARTINSSON, AND \\ ALICE C. YAO \\ Departments of Clinical Pharmacology and Pediatrics, Karolinska Hospital and Departments of Neurophysiology \\ and Pharmacology, Karolinska Institute, Stockholm, Sweden
}

\begin{abstract}
The maturity of $\beta$-adrenoceptors in newborn infants was studied in relation to the catecholamine surge during labor. Umbilical blood was collected at birth from 12 infants delivered vaginally and 13 infants delivered by elective cesarean section. Granulocytes and lymphocytes were isolated. Receptor numbers and binding affinity were determined in the granulocytes by incubation with ${ }^{125} \mathrm{I}$ iodohydroxybenzylpindolol. Receptor responsiveness was tested by assessing isoproterenol-induced cyclic AMP accumulation in lymphocytes. Significantly higher plasma noradrenaline, adrenaline, and dopamine concentrations were found in infants born vaginally $(108 ; 8.9 ; 0.9 \mathrm{nmol} /$ liter, respectively, median values) as compared with those delivered by cesarean section $(11.0 ; 2.4 ; 0.2$ nmol/liter $)$. No significant differences in $\beta$-adrenoceptor binding sites (receptor number: $39.2 \pm 2.6$ versus $44.7 \pm 5.9 \mathrm{fmol} / \mathrm{mg}$ protein and binding affinity: $66.6 \pm 7.8$ versus $65.0 \pm 6.2$ pM) or responsiveness (maximal isoprenaline induced cAMP formation $52.4 \pm 10.3$ versus $40.6 \pm 8.9 \mathrm{pmol} / 10^{6}$ cells) were found between the two groups of infants. Lymphocyte $\beta$-adrenoceptor sensitivity was similar to that found in adults. The $\beta$-adrenoceptors on whole blood cells seem to be mature at birth and have the same responsiveness as in adults. The higher catecholamine surge during vaginal delivery as compared to elective cesarean section does not seem to affect $\beta$-adrenoceptor function. Our results do not support the idea that reduced $\beta$-adrenoceptor function is the cause of the previously observed inappropriately small cardiovascular and metabolic responses to the exceptionally high plasma catecholamine concentrations at birth. (Pediatr Res 20: 1152-1155, 1986)
\end{abstract}

\section{Abbreviations}

CA, catecholamines

$B_{\text {max }}$, receptor number

$K_{\mathfrak{D}}$, binding affinity

cAMP, cyclic adenosine monophosphate

${ }^{125}$ IHYP, ${ }^{125}$ I-iodohydroxybenzylpindolol

The fetal sympathoadrenal system is markedly activated during vaginal delivery and particularly during perinatal asphyxia

Received January 7, 1986; accepted June 19, 1986.

Correspondence Dr. Hugo Lagercrantz, Department of Pediatrics, Karolinska Hospital, S-104 01 Stockholm, Sweden.

This research was supported by the Swedish Medical Research Council (Projects 522, 5234 and 5930), Expressen's Prenatal Foundation, Stiftelsen Allmänna B.B., The Swedish Society for Medicine, and the Karolinska Institute. A.C.Y. collaborated during sabbatical leave from Downstate Medical Center, State University of New York, Brooklyn. NY.
(1-5). The plasma CA concentrations found in the umbilical artery after uneventful vaginal deliveries are about 20 -fold higher and, during perinatal asphyxia, up to 100 -fold higher than in resting adults $(1,6)$. This CA surge might be of importance for neonatal adaptation after birth. CA have been demonstrated to stimulate lung liquid absorption $(7,8)$, enhance surfactant release (7), increase dynamic lung compliance (9), mobilize glucose and free fatty acids $(10,11)$, increase cardiac performance (12), and mediate shunting of blood to the most vital organs $(13,14)$. The cardiovascular and metabolic responses to these enormous concentrations of $\mathrm{CA}$ are, however, relatively small. Thus, blood pressures and heart rates are only slightly higher in vaginally delivered infants than in infants delivered by elective cesarean section (14) despite a 5- to 6-fold difference in CA levels (4). The plasma glucose and glycerol concentrations are lower in relation to the CA concentrations than would be expected from results obtained in adults (11).

One possible explanation for these findings may be fetal shunting of blood. Other possibilities to be considered are immaturity of the adrenergic receptors (15) or down-regulation of the $\beta$ adrenoceptors due to the CA surge. A reduced number of $\beta$ adrenoceptor binding sites and reduced responsiveness (isoproterenol induced cAMP accumulation) have been reported in neonatal granulocytes, as compared to those of adults (16).

The aim of the present study was to investigate further the relationship between $\beta$-adrenoceptor function and sympathoadrenal activity in newborn infants. We studied the relationship between plasma $\mathrm{CA}$ levels and the responsiveness of the $\beta$ adrenoceptors by comparing vaginally delivered infants, who were expected to have high CA levels, with those delivered by elective cesarean section, who were expected to have lower CA levels. Maturation of $\beta$-adrenoceptor-mediated function may involve both formation of the receptors, coupling to second messenger systems and intracellular mechanisms. Therefore, we studied isoprenaline-induced cAMP formation as a measure of receptor mediated functional responsiveness and more specific receptor characteristics, as obtained by receptor ligand binding techniques. To ensure assessments of both receptor binding and responsiveness when the amount of placental blood sampled was limited, we isolated both granulocytes, which were used to determinate $B_{\max }$ and $K_{D}$ values for ${ }^{125} \mathrm{IHY} \mathrm{P}$, and lymphocytes, which were used for studies of $\beta$-adrenoceptor responsiveness. This approach, using two cell types, does not limit the comparisons between vaginally delivered infants and those delivered by cesarean section. For example, both granulocytes and lymphocytes have been reported to be desensitized by exposure to $\beta$-agonists $(17,18)$.

\section{MATERIALS AND METHODS}

Patients. Fetal placental and mixed umbilical blood was collected with a special funnel from 25 full-term infants, delivered 
after uncomplicated pregnancies. None of the mothers had received any medication except iron and vitamins. Twelve of the infants were delivered vaginally and 13 by elective cesarean section, usually under epidural analgesia as previously described (4). The parents were informed about the study which was approved by the local Ethics Committee.

Cell preparation. Lymphocytes were isolated by density gradient centrifugation using Ficoll-Paque (Pharmacia, Uppsala, Sweden) according to instructions from the company. Blood was collected from the umbilical cord and placenta. The blood was mixed with an equal volume of a balanced salt solution containing heparin. This mixture was carefully layered on the FicollPaque solution and centrifuged at $400 \times g$ at $18^{\circ} \mathrm{C}$ for $30 \mathrm{~min}$. After removing the majority of the plasma layer, the lymphocyte coat, was carefully collected using a siliconized pasteur pipette. This cell suspension was washed twice and finally resuspended in Dulbecco's phosphate-buffered saline containing $5.5 \mathrm{mM}$ glucose. After removal of the Ficoll-Paque layer, the pellet containing erythrocytes and granulocytes was resuspended in $10 \mathrm{ml}$ $0.9 \% \mathrm{NaCl}$ and thereafter mixed with $25 \mathrm{ml} 6 \%$ Dextran T 70 with $10 \%$ bovine serum albumin in saline. The erythrocytes were left to sediment for $30 \mathrm{~min}$ after which the supernatant was collected and centrifuged for $10 \mathrm{~min}$ at $200 \times g$ at $4^{\circ} \mathrm{C}$. The remaining erythrocytes were lysed by a brief exposure to ice cold $0.2 \% \mathrm{NaCl}$. After removal of the lysed erythrocytes, granulocyte membranes were prepared by lysis and homogenization of the cells (using a Polytron homogenizer). The membrane preparation was stored frozen at $-80^{\circ} \mathrm{C}$ until the $\beta_{2}$-adrenoceptor binding assay was performed

Cell incubation. Lymphocytes $\left(2-2.5 \times 10^{6}\right.$ cells $\left./ \mathrm{ml}\right)$ were incubated without (basal) or with isoproterenol $\left(10^{-9}-10^{-4} \mathrm{M}\right)$ in a final volume of $200 \mu \mathrm{l}$ at $37^{\circ} \mathrm{C}$ for $20 \mathrm{~min}$. The incubations were performed in the presence of the phosphodiesterase inhibitor 3-isobutyl-1-methylxanthine $(0.5 \mathrm{mM})$ and were run in triplicates at each isoproterenol concentration. The reaction was stopped by heating to $95^{\circ} \mathrm{C}$ for $3 \mathrm{~min}$ and the samples subsequently frozen and stored at $-20^{\circ} \mathrm{C}$ until analyzed for cAMP contents.

Binding assay. Granulocyte membranes were incubated in duplicate in the presence and absence of $1 \mu \mathrm{M}$ propranolol at six concentrations (10-200 pM) of ${ }^{125}$ IHYP. The incubation buffer consisted of $0.9 \% \mathrm{NaCl}$ with $10 \mathrm{mM}$ Tris, $\mathrm{pH} 7.5$ containing 1 $\mathrm{mM}$ ascorbic acid, $50 \mu \mathrm{M}$ phentolamine, and $1 \mu \mathrm{g}$ albumin in a final volume of $300 \mu \mathrm{l}$. Samples were incubated for $1 \mathrm{~h}$ at $37^{\circ} \mathrm{C}$, after which the incubates were diluted by adding $10 \mathrm{ml} 0.9 \%$ $\mathrm{NaCl}$ containing $10 \mathrm{mM}$ Tris, $\mathrm{pH} 7.5$ and rapidly filtered through Whatman GFC filters presoaked in this buffer solution. The filters were immediately (within $10 \mathrm{~s}$ ) washed with $10 \mathrm{ml}$ buffer The binding fulfilled conventional criteria for saturability and stereo-selectivity. Values for $K_{D}$ and $B_{\max }$ were calculated from Scatchard plots. The $r$ values for the 6 point regression lines were all above 0.88 and the majority were above 0.95 . Figure 1 shows a representative saturation curve and Scatchard plot from one experiment.

Other assays. Plasma catecholamines were determined by high-performance liquid chromatography with electrochemical detection (19). Cyclic AMP was determined by a protein binding method (20) and the protein contents of the granulocyte membrane preparations were determined according to Lowry et al. (21).

Statistics. All results are expressed as median and range values or as mean values \pm SEM. Mann-Whitney U test, or Student's $t$ test, when appropriate, were used for statistical comparisons. A level of $p<0.05$ was considered as significant.

\section{RESULTS}

Patient data and plasma CA concentrations are summarized in Table 1. None of the vaginally delivered infants had an Apgar score below 6 at $1 \mathrm{~min}$ although some of the infants were acidotic as usually found in a "normal" material (22). The numbers of

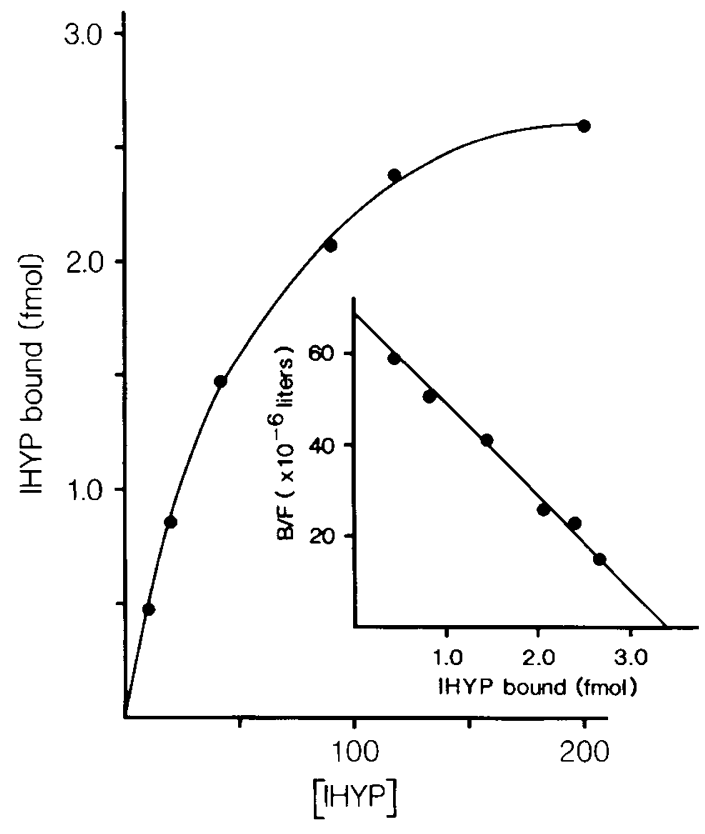

Fig. 1. Binding of ${ }^{125} \mathrm{IHYP}$ to granulocyte membranes from one of the assays in the study. The amount of specifically bound ${ }^{125} \mathrm{IHYP}(\mathrm{fmol})$ was saturable with increasing concentration of ${ }^{125} \mathrm{IHYP}$ (pmol). The inset shows a Scatchard plot of data, from which the $K_{D}$ and $B_{\max }(49.2 \mathrm{pM}$ and $63.0 \mathrm{fmol} / \mathrm{mg}$ protein, respectively, in this experiment) can be calculated.

Table 1. Patient data (median and range)*

\begin{tabular}{lcc}
\hline & Vaginal delivery & Cesarean section \\
\hline Birth wt $(\mathrm{g})$ & $3367(2970-4180)$ & $3583(3110-4640)$ \\
& $n=12$ & $n=13$ \\
Placental wt $(\mathrm{g})$ & $560(420-730)$ & $651(450-820)$ \\
& $n=12$ & $n=13$ \\
Sex $(\mathrm{M} / \mathrm{F})$ & $2 / 10$ & $8 / 5$ \\
$\mathrm{pH}$ & $7.18(7.02-7.34)$ & $7.30(7.29-7.31)$ \\
& $n=8$ & $n=5$ \\
Hematocrit (\%) & $51.9(45.0-57.0)$ & $44.2(30.0-56.0)$ \\
& $n=10$ & $n=9$ \\
Catecholamines (nmol/liter) & & \\
Noradrenaline & $108.0(6.8-539.3)$ & $11.0(1.8-37.4)$ \\
& $n=11$ & $n=12$ \\
Adrenaline & $8.9(0-35.9)$ & $2.4(0-11.8)$ \\
& $n=11$ & $n=12$ \\
Dopamine & $0.9(0-2.6)$ & $0.2(0-0.8)$ \\
& $n=11$ & $n=12$ \\
\hline
\end{tabular}

* The differences in catecholamine levels between the two patient groups were statistically significant ( $p<0.05$, Mann-Whitney $U$ test) for all catecholamines. $\mathrm{pH}$ and hematocrit values were statistically different ( $p<0.05$, Student's $t$ test for unpaired variates) between the two groups.

the receptor binding sites in the granulocytes and their affinities, as well as the basal and maximally stimulated cAMP concentrations in the lymphocytes are presented in Table 2 . The plasma CA concentrations were higher, in individual cases considerably higher, in the vaginal group than in the infants delivered by cesarean section. However, no significant differences in $\mathrm{B}_{\max }$ or $\mathrm{K}_{\mathrm{D}}$ for ${ }^{125} \mathrm{IHYP}$ or isoproterenol-stimulated cAMP formation were observed. The individual results concerning isoproterenolstimulated cAMP formation are shown in Figure 2. The lymphocytes from one infant responded with exceptionally high cAMP formation (Fig. 2, top curve). This infant was delivered vaginally and was asphyxiated (pH 7.11, Apgar score 6 at $1 \mathrm{~min}$ ) and had the highest CA level of all babies $(539 \mathrm{nmol} /$ liter noradrenaline and $22.0 \mathrm{nmol} /$ liter adrenaline). 
Table 2. $B_{\max }$ and $K_{D}$ of $\beta$-adrenoceptors of granulocytes $(A)$ and isoproterenol-induced cAMP formation in lymphocytes $(B)$ [mean $\pm S E M(n)]$

\begin{tabular}{lcr} 
& Vaginal & Cesarean section \\
\hline A. & & \\
$\mathrm{B}_{\max }(\mathrm{fmol} / \mathrm{mg}$ protein) & $39.2 \pm 2.6(11)$ & $44.7 \pm 5.9(12)$ \\
$\mathrm{K}_{\mathrm{D}}(\mathrm{pM})$ & $66.6 \pm 7.8(11)$ & $65.0 \pm 6.2(12)$ \\
& & \\
B. & & \\
Concentration (pmol/106 cells) & & \\
$\quad$ Basal & $3.8 \pm 1.1(11)$ & $4.6 \pm 1.6(7)$ \\
$\quad$ Maximal & $52.4 \pm 10.3(11)$ & $40.6 \pm 8.9(7)$ \\
$\mathrm{EC}_{50}(\mathrm{nM})$ & $32.4 \pm 8.9(11)$ & $19.6 \pm 4.3(7)$ \\
\hline
\end{tabular}

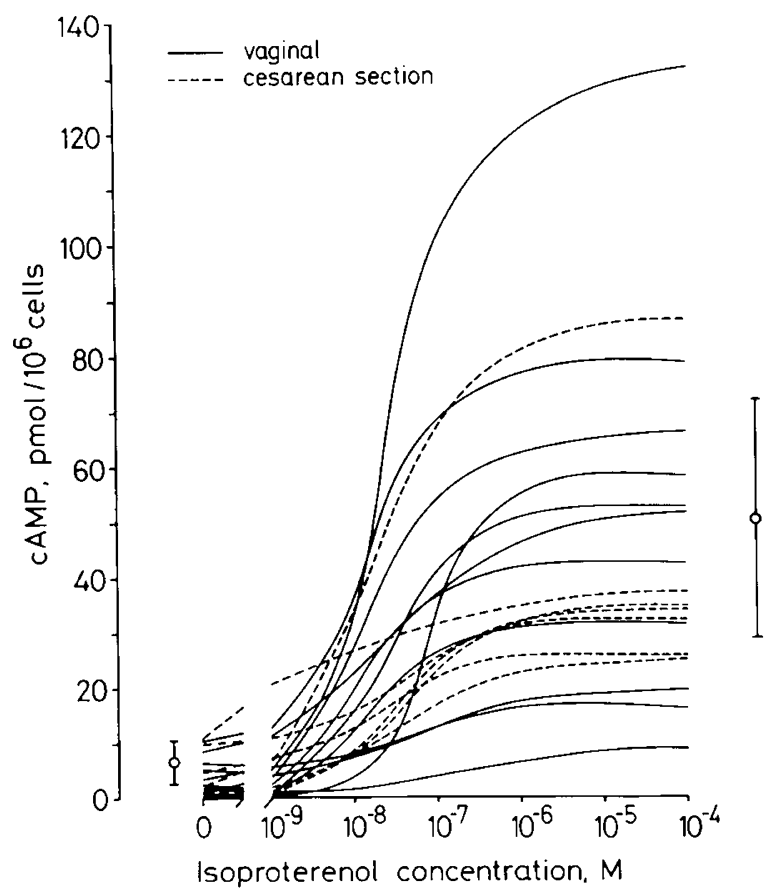

Fig. 2. Stimulation of cAMP formation by isoproterenol in the presence of the phosphodiesterase inhibitor IBMX. Values (mean \pm SD) for adult lymphocytes obtained in the same laboratory are also shown for comparison (left vertical bar: resting values without isoproterenol $=7.1$ $\pm 4.1, n=22$; right vertical bar: values at an isoproterenol concentration of $10^{-4} \mathrm{M}=51.1 \pm 21.5, n=22$ ).

No significant correlations were found between either noradrenaline or adrenaline concentrations in plasma at birth and lymphocyte $\beta$-adrenoceptor responsiveness whether absolute values or logarithmically transformed CA values were used in the calculations. No sex differences were observed with regard to $\mathrm{B}_{\max }$ or $\mathrm{K}_{\mathrm{D}}$ values. Plasma CA levels and lymphocyte responses to isoproterenol were slightly higher in the boys than in the girls, but the differences were not significant.

The infants were also grouped according to gestational age: less than 39 or 39 wk and more. No significant differences with regard to beta-adrenoceptor numbers or responsiveness were found. On the other hand, there was a significant inverse relationship between cAMP formation and birth weight (Fig. 3).

\section{DISCUSSION}

We studied $\beta$-adrenoceptor function in white blood cells from newborn infants by determining the numbers and affinities of $\beta$ adrenergic binding sites in granulocytes as well as $\beta$-adrenoceptor responsiveness of lymphocytes isolated from fetal placental blood. The properties of the white blood cell receptors were

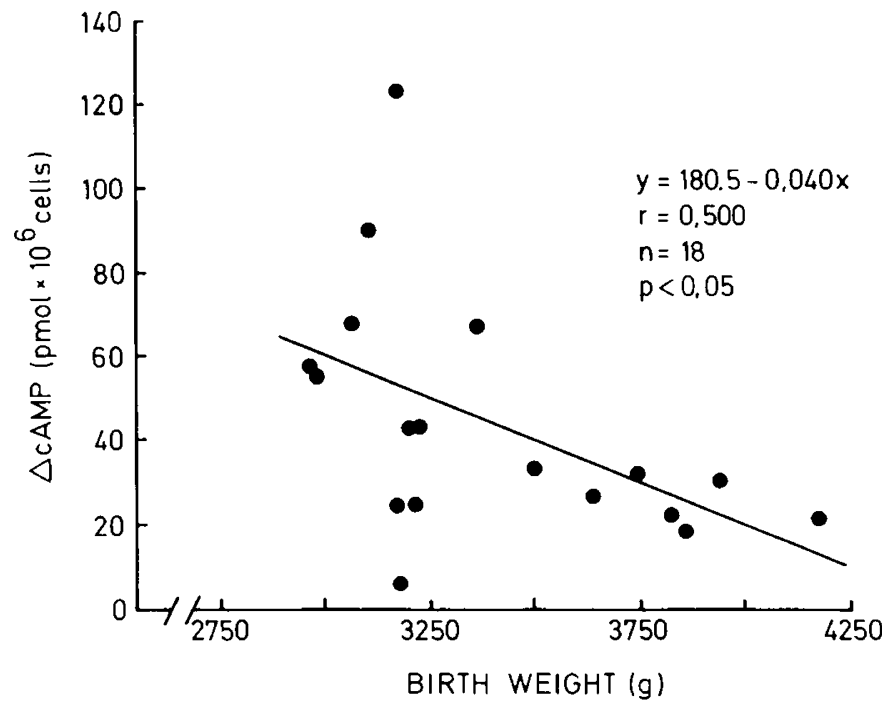

Fig. 3. Correlation between maximal increase in isoproterenol-induced cAMP formation and birth weight of the infants.

found to be similar to those in adults, in contrast to an earlier study (16) which reported that granulocytes from six newborn babies contained fewer $\beta$-adrenoceptors and also a reduced cAMP response to isoproterenol stimulation than those from six healthy adults. However, the $\beta$-adrenoceptor numbers reported for the adults in that study are considerably higher than those reported in previous studies from the same group $(23,24)$, suggesting that the choice of controls may have influenced the results and interpretations.

In a recent report O'Hara et al. (25) found fewer binding sites for the $\beta$-adrenoceptor ligand ${ }^{125}$ iodocyanopindolol in intact lymphocytes from vaginally delivered infants than in adult lymphocytes. They also found lower cAMP levels in lymphocyte incubates with and without isoproterenol. Our results, obtained in granulocyte membranes and intact lymphocytes, respectively, are clearly at variance with these previous reports and do not support the idea of a reduced $\beta$-adrenoceptor function in the neonatal period.

To study whether the CA surge during labor $(6,26)$ could modify $\beta$-adrenoceptor function, we compared infants delivered vaginally with those born by cesarean section, since the latter group of infants has been shown to have considerably lower CA levels (4). However, we found no significant differences in either $\mathrm{B}_{\max }, \mathrm{K}_{\mathrm{D}}$, or stimulated cAMP-formation between the two groups of infants, despite the expected differences in plasma CA levels. Furthermore, there was no significant relationship between $\mathrm{CA}$ levels at birth and $\beta$-adrenoceptor numbers and properties.

We cannot exclude the possibility that the enhanced CA surge in the vaginal group induced a minor change in agonist affinity for the $\beta$-adrenoceptors, as the $\mathrm{EC}_{50}$ values for isoprenalineinduced cAMP formation were somewhat higher (although not significantly) in the vaginal group. Thus, Feldman et al. (27) reported that white blood cells from subjects changing from the supine position to being ambulatory showed a decrease in high affinity binding sites for agonists with a parallel decrease in adenylate-cyclase function, without changes in the total number of receptors. This was suggested to be caused by the increase in $\mathrm{CA}$ levels when rising from the supine position.

One asphyxiated infant with extremely high CA levels also had the highest $\beta$-adrenoceptor responsiveness (isoproterenol-induced cAMP formation). This might be due to the transient upregulation of receptors which has been found to precede downregulation in connection with epinephrine or isoproterenol exposure (28) and also after exercise in adults (29). Except in one of our patients, the higher CA levels during vaginal delivery did not seem to have modified $\beta$-adrenoceptor function. 
No sex differences in $\beta$-adrenoceptor properties were found in this study. However, it is difficult to draw any definitive conclusion since the sex distribution in the two groups was uneven. This question is of some interest since enhanced maturation of $\beta$-adrenoceptors in the lung due to the influence of sex steroids might be one factor explaining why newborn girls less frequently develop respiratory problems (30).

There was no relationship between gestational age (from the 36 th wk) and $\beta$-adrenoceptor properties in the present study. On the other hand, there was a significant inverse relationship between $\beta$-adrenoceptor function and birth weight. Growth-retarded fetuses have elevated plasma corticosteroid and thyroid hormone levels both of which may influence $\beta$-adrenoceptor function $(15,31)$. None of the infants in the present study was growth retarded according to conventional clinical criteria, but it is possible that a slight but clinically insignificant retardation of growth in some of these infants was sufficient to stimulate steroid hormone release and subsequently enhance $\beta$-adrenoceptor formation.

One of the main reasons for undertaking the present study was the previous observation that the high CA surge during vaginal birth is associated with relatively modest effects on circulation and metabolism (11). The present results indicate that these small circulatory and metabolic responses were not caused by immaturity of the $\beta$-adrenoceptors. However, we only studied $\beta$ adrenoceptors in white blood cells and it is possible that the function of these receptors may differ from the function of those in other tissues. However, one animal study (32) has clearly shown that there are parallel changes of $\beta$-adrenoceptors in granulocytes and other tissues, such as the heart and lung, during treatment with propranolol. In man, the receptor number on leucocytes have been reported to correlate with changes in cardiac responsiveness to isoproterenol (33). Thus, it seems reasonable to speculate that our results indicate a normal maturity of the neonatal $\beta$-adrenoceptors also in other tissues.

Acknowledgments. The authors thank Ms Ingrid Dahlin and Ms Birgitta Pettersson for excellent technical assistance.

\section{REFERENCES}

1. Lagercrantz H, Bistoletti $P 1977$ Catecholamine release in the newborn infant at birth. Pediatr Res 2:889-893

2. Artal R, Lam RW, Eliot J, Hobel CJ, Fisher DA 1979 Circulating catecholamines prior to and after delivery. In: Usdin E, Kopin IJ, Barchas J (eds) Catecholamines: Basic and Clinical Frontiers. Pergamon Press, New York, pp 951-954

3. Eliot RJ, Lam R, Leake R, Hobel CJ, Fisher DA 1980 Plasma catecholamine concentrations in infants at birth and during the first 48 hours of life. J Pediatr 96:311-315

4. Irestedt L, Lagercrantz H, Hjemdahl P, Hägnevik K, Belfrage P 1982 Fetal and maternal plasma catecholamine levels at elective cesarean section in general or epidural anesthesia versus vaginal delivery. Am J Obstet Gynecol 142:1004-1010

5. Padbury J, Roberman B, Oddie TH, Hobel CJ, Fisher DA 1982 Fetal catecholamine release in response to labor and delivery. Obstet Gynecol 60:607611

6. Nylund L, Lagercrantz H, Lunell N-O 1979 Catecholamines in fetal blood during birth in man. J Dev Physiol 1:427-430

7. Lawson EE, Brown ER, Torday JS, Madansky DL, Taeusch HW Jr 1978 The effect of epinephrine on tracheal fluid flow and surfactant efflux in fetal sheep. Am Rev Respir Dis 118:1023-1026
8. Walters DV, Oliver RE 1978 The role of catecholamines in lung liquid absorption at birth. Pediatr Res 12:239-242

9. Faxelius G, Hägnevik K, Lagercrantz H, Lundell B, Irestedt L 1983 Catecholamine surge and lung function after delivery. Arch Dis Child 58:262-266

10. Sperling MA, Christensen RA, Ganguli, S, Anand R 1980 Adrenergic modu lation of pancreatic hormone secretion in utero: studies in fetal sheep. Pediatr Res 14:203-208

11. Hägnevik K, Faxelius G, Irestedt L, Lagercrantz H, Lundell B, Persson B 1984 Catecholamine surge and metabolic adaptation in the newborn after vaginal delivery and cesarean section. Acta Paediatr Scand 73:602-609

12. Downing SE, Lee JC 1983 Analysis of cardiac adrenergic mechanisms in hypoxic lambs. Am J Physiol 244:H222-227

13. Cohn HE, Sacks EJ, Heymann MA, Rudolph AM 1974 Cardiovascular responses to hypoxemia and acidemia in fetal lambs. Am J Obstet Gynecol 120:817-824

14. Faxelius G, Lagercrantz H, Yao A 1984 Sympathoadrenal activity and peripheral blood flow after birth: Comparison in infants delivered vaginally and by cesarean section. J Pediatr 105:144-148

15. Whitsett JA, Noguchi A, Moore JJ 1982 Developmental aspects of alfa and beta adrenergic receptors. Seminars in Perinatology 6:125-141.

16. Roan Y, Galant SP 1982 Decreased neutrophil beta adrenergic receptors in the neonate. Pediatr Res 16:591-593

17. Galant SP, Duriseti L, Underwood S, Insel PA 1978 Decreased beta-adrenergic receptors on polymorphonuclear leukocytes after adrenergic therapy. N Engl J Med 29:933-936

18. Greenacre JK, Conolly ME 1978 Desensitization of the $\beta$-adrenoceptor of lymphocytes from normal subjects and patients with phaeochromocytoma: studies in vivo. Br J Clin Pharmacol 5:191-197

19. Hjemdahl P, Daleskog M, Kahan T 1979 Determination of plasma catecholamines by high performance liquid chromatography with electrochemical detection: comparison with a radioenzymatic method. Life Sci 225:131-138

20. Brown BL, Enkins RP, Albano JDM 1972 Saturation assay for cyclic AMP using endogenous binding protein. Adv Cyclic Nucleotide Res 2:25-40

21. Lowry OH, Rosebrough NJ, Farr ASL, Randall RJ 1951 Protein measurement with the Folin phenol reagent. J Biol Chem 193:265-275

22. Sykes GS, Molloy PM, Johnson P, Gu W, Ashworth F, Stirrat GM, Turnbull AC 1982 Do Apgar scores indicate asphyxia? Lancet 1:494-496

23. Galant SP, Allred S 1981 Binding and functional characteristics of beta adrenergic receptors in the intact neutrophil. J Lab Clin Med 98:227-237

24. Galant SP, Norton L, Herbst J, Wood, C 1981 Impaired beta adrenergic receptor binding and function in cystic fibrosis neutrophils. $\mathrm{J}$ Clin Invest 68:253-258

25. O'Hara N, Daul AE, Fesel R, Siekmann U, Brodde O-E 1985 Different mechanisms underlying reduced $\beta_{2}$-adrenoceptor responsiveness in lymphocytes from neonates and old subjects. Mech Ageing Dev 31:115-122

26. Bistoletti P, Nylund L, Lagercrantz H, Hjemdahl P, Ström H 1983 Fetal plasma catecholamine levels during first stage of labor: Correlation with cervix dilation, maternal analgesia, fetal blood $\mathrm{pH}$ and fetal heart rate patterns. Am J Obstet Gynecol 147:785-788

27. Feldman RD, Limbird LE, Nadeau J, FitzGerald GA, Robertson D, Wood AJJ 1983 Dynamic regulation of leukocyte beta adrenergic receptor-agonist interactions by physiological changes in circulating catecholamines. $\mathbf{J}$ Clin Invest 72:164-170

28. Tomeh JF, Cryer PE 1980 Biphasic adrenergic modulation of beta adrenergic receptors in man. J Clin Invest 65:836-840

29. Brodde OE, Daul A, O'Hara N 1984 Beta-adrenoceptor changes in human lymphocytes, induced by dynamic exercise. Naunyn Schmiedebergs Arch Pharmacol 325:190-192

30. Padbury JF, Hobel CJ, Lam RW, Fischer DA 1981 Sex differences in lung and adrenal neurosympathetic development in rabbits. Am J Obstet Gynecol 141:199-204

31. Cheng JB, Goldfien A, Ballard PL, Roberts JM 1980 Glucocorticoids increase pulmonary beta-adrenergic receptors in fetal rabbit. Endocrinology 107:1646-1648

32. Aarons RD, Molinoff PB 1982 Changes in the density of beta adrenergic receptors in rat lymphocytes, heart and lung after chronic treatment with propranolol. J Pharmacol Exp Ther 221:439-443

33. Fraser J, Nadeau J, Robertson D, Wood, AJJ 1981 Regulation of human leucocyte beta receptors by endogenous catecholamines. Relationship of leucocyte beta receptor density to the cardiac sensitivity to isoproterenol. J Clin Invest 67:1777-1784 